\title{
Regulation of the Inositol 1,4,5-Trisphosphate Receptor Type I by 0 -GlcNAc Glycosylation
}

\author{
Juliana Rengifo, ${ }^{1}$ Craig J. Gibson, ${ }^{1}$ Eva Winkler, ${ }^{1}$ Thibault Collin, ${ }^{2}$ and Barbara E. Ehrlich ${ }^{1}$ \\ ${ }^{1}$ Department of Pharmacology and Cellular and Molecular Physiology, Yale University, New Haven, Connecticut 06520, and ${ }^{2}$ Laboratoire de Physiologie \\ Cérébrale, Université Paris 5, 75006 Paris, France
}

\begin{abstract}
The inositol 1,4,5-trisphosphate $\left(\mathrm{InsP}_{3}\right)$ receptor type I $\left(\mathrm{InsP}_{3} \mathrm{R}-\mathrm{I}\right)$ is the principle channel for intracellular calcium $\left(\mathrm{Ca}^{2+}\right)$ release in many cell types, including central neurons. It is regulated by endogenous compounds like $\mathrm{Ca}^{2+}$ and ATP, by protein partners, and by posttranslational modification. We report that the $\operatorname{Ins}_{3} \mathrm{R}$-I is modified by $O$-linked glycosylation of serine or threonine residues with $\beta$ - $N$-acetylglucosamine ( 0 -GlcNAc). The level of $O$-GlcNAcylation can be altered in vitro by the addition of the enzymes which add [OGT ( $O$-GlcNActransferase)] or remove ( $O$-GlcNAcase) this sugar or by loading cells with UDP-GlcNAc. We monitored the effects of this modification on $\mathrm{Ins}_{3} \mathrm{R}$ function at the single-channel level and on intracellular $\mathrm{Ca}^{2+}$ transients. Single-channel activity was monitored with Ins $\mathrm{P}_{3} \mathrm{R}$ incorporated into bilayers; $\mathrm{Ca}^{2+}$ signaling was monitored using cells loaded with a $\mathrm{Ca}^{2+}$-sensitive fluorophore. We found that channel activity was decreased by the addition of $O$-GlcNAc and that this decrease was reversed by removal of the sugar. Similarly, cells loaded with UDP-GlcNAc had an attenuated response to uncaging of $\mathrm{InsP}_{3}$. These results show that $O$-GlcNAcylation is an important regulator of the $\mathrm{InsP}_{3} \mathrm{R}$-I and suggest a mechanism for neuronal dysfunction under conditions in which $\mathrm{O}$-GlcNAc is high, such as diabetes or physiological stress.
\end{abstract}

Key words: calcium imaging; calcium-sensitive dye; $\beta$ - $N$-acetylglucosamine; $O$-GlcNActransferase; $O$-GlcNAcase; cerebellum; interneurons; inositol 1,4,5-trisphosphate receptor

\section{Introduction}

Inositol 1,4,5-trisphosphate $\left(\mathrm{InsP}_{3}\right)$-mediated $\mathrm{Ca}^{2+}$ release from intracellular stores controls a variety of cellular processes including cell growth, fertilization, secretion, smooth muscle contraction, and neuronal signaling (Berridge, 1993). The $\mathrm{InsP}_{3}$ receptor type I ( InsP $\left.\mathrm{P}_{3} \mathrm{R}-\mathrm{I}\right)$, the most well studied of the three $\mathrm{InsP}_{3} \mathrm{R}$ isoforms, is involved in the regulation of neuronal functions such as long-term potentiation and depression (Nagase et al., 2003).

The InsP $\mathrm{P}_{3} \mathrm{R}-\mathrm{I}$ is regulated by endogenous compounds such as InsP $\mathrm{P}_{3}, \mathrm{Ca}^{2+}$, and ATP, and modulated by associated proteins such as calmodulin and chromogranin (Ehrlich et al., 1994; Thrower et al., 2003; Bezprozvanny, 2005; Choe and Ehrlich, 2006). The Ins $\mathrm{P}_{3} \mathrm{R}-\mathrm{I}$ is also regulated by posttranslational modifications. For example, phosphorylation by PKA (protein kinase A) or tyrosine kinases increases channel activity, and the func-

Received May 6, 2007; revised Sept. 25, 2007; accepted Sept. 26, 2007.

This work was supported by grants from the Diabetes Endocrinology Research (enter and the National Institutes of Health (B.E.E.), Centre National de la Recherche Scientifique (T.C., B.E.E.), a Howard Hughes Medical Institute predoctoral fellowship (C.J.G.), and a German National Merit Foundation scholarship (E.W.). We thank Natasha Zachara and Gerald Hart for teaching us about the GICNAC pathway and its importance in cellular regulation. We also thank Isabel Llano, Alain Marty, Benedicte Rossi, and Brenda DeGray for thoughtful discussions about the experiments and comments on this manuscript.

Correspondence should be addressed to Barbara E. Ehrlich, Department of Pharmacology, 333 Cedar Street, Yale University, New Haven, С 06520-8066. E-mail: barbara.ehrlich@yale.edu.

J. Rengifo's present address: Department of Anatomy, 1215 Linden Drive, University of Wisconsin, Madison, WI 53706.

E. Winkler's present address: Department of Pharmacology, University of Cologne, Gleueler Strasse 24, 50931 Cologne, Germany.

DOI:10.1523/JNEUROSCI.2069-07.2007

Copyright $\odot 2007$ Society for Neuroscience 0270-6474/07/2713813-09\$15.00/0 tional sites of phosphorylation have been identified (Jayaraman et al., 1996; Wojcikiewicz and Luo, 1998; Tang et al., 2003). The $\mathrm{Ins}_{3} \mathrm{R}-\mathrm{I}$ is also posttranslationally modified by $\mathrm{N}$-glycosylation, and the sites of modification are known (Michikawa et al., 1994). However, functional changes have not been identified with this modification.

Another class of posttranslational modification is $\mathrm{O}$-GlcNAcylation, a type of $O$-linked glycosylation in which $\beta-N$ acetylglucosamine (O-GlcNAc) is added to serine or threonine residues (Wells and Hart, 2003). Classical $O$-linked and $N$-linked glycosylation occurs in the secretory pathway, with the enzymes involved residing in the endoplasmic reticulum and the Golgi apparatus, and glycosylation occurring on lumenal residues. This irreversible type of glycosylation regulates protein folding, targeting, and turnover (Helenius and Aebi, 2004). In the case of $O$-GlcNAcylation, O-GlcNActransferase (OGT) and $O$-GlcNAcase, the enzymes that add and remove O-GlcNAc to proteins, reside in the cytoplasm and the nucleus, and $O$-GlcNAcylation occurs on the nucleoplasmic and cytoplasmic domains of proteins. OGT and O-GlcNAcase have been cloned, and $O$-GlcNAcase has been characterized for in vitro use (Kreppel et al., 1997; Gao et al., 2001).

O-GlcNAcylation is an abundant, dynamic, and inducible modification that shares common characteristics with protein phosphorylation. Proteins modified by $\mathrm{O}$-GlcNAc include transcription factors, signaling components, and metabolic enzymes. Changes in the level of $O$-GlcNAcylation of several of these proteins are known to regulate their activity by modulating either 
protein phosphorylation, protein-protein interactions, or subcellular localization (Wells and Hart, 2003). O-GlcNAcylation has also been shown to play a role in the regulation of $\mathrm{InsP}_{3}$ mediated $\mathrm{Ca}^{2+}$ signaling. Cardiomyocytes of diabetic rats show altered $\mathrm{Ca}^{2+}$ transients that can be restored to normal by decreasing the cellular O-GlcNAcylation level (Clark et al., 2003). Cardiomyocytes show an elevation of cytoplasmic $\mathrm{Ca}^{2+}$ in response to the $\mathrm{Ins}_{3}$-generating agonist angiotensin II. This response can be blocked by inducing an increase in protein $O$-GlcNAcylation (Nagy et al., 2006).

Here, we demonstrate for the first time that the $\mathrm{InsP}_{3} \mathrm{R}-\mathrm{I}$ is modified by $\mathrm{O}-\mathrm{GlcNAc}$. Moreover, we show that the $\mathrm{O}$-GlcNAc modification regulates the $\mathrm{InsP}_{3} \mathrm{R}-\mathrm{I}$ at the single-channel level: addition of the $O$-GlcNAc group has a functional effect on the channel. InsP $\mathrm{P}_{3}$-induced $\mathrm{Ca}^{2+}$ release decreases with $\mathrm{O}$-GlcNAcylation and increases with de-O-GlcNAcylation. This effect is specific for InsP ${ }_{3} \mathrm{R}-\mathrm{I}$, because there is no functional effect of $O$-GlcNAc on the ryanodine receptor (RyR). We also show for the first time that cerebellar interneurons have an $\mathrm{InsP}_{3}$ dependent increase in intracellular $\mathrm{Ca}^{2+}$ and that this increase can be modulated by O-GlcNAc. We speculate that this may be partially responsible for improper neuronal signaling under conditions such as diabetes, when cellular UDP-GlcNAc levels are elevated (Robinson et al., 1995).

\section{Materials and Methods}

All procedures for animal use were in accordance with guidelines approved by the host institutions where experimental work was performed, namely the University of Paris 5 and Yale University.

Ins $P_{3} R-I$ immunoprecipitation and purification. Mice cerebella (PelFreez Biologicals, Rogers, AR) were homogenized in $10 \mathrm{vol}$ of buffer A (50 mu Tris-HCl, 1 mM EDTA, 1 mm 2- $\beta$-mercaptoethanol, $\mathrm{pH}$ 8.3, and protease inhibitors). After centrifugation $\left(1000 \times g\right.$ for $10 \mathrm{~min}$ at $\left.4^{\circ} \mathrm{C}\right)$, the supernatant was further centrifuged at $100,000 \times g$ for $30 \mathrm{~min}$. The pellet was then resuspended in lysis buffer $(50 \mathrm{~mm}$ Tris- $\mathrm{HCl}, 100 \mathrm{~mm}$ $\mathrm{NaCl}, 1$ mм EDTA, 1 mм DTT, 1\% Triton X-100, pH 8.3, and protease inhibitors) and incubated for $30 \mathrm{~min}$ at $4^{\circ} \mathrm{C}$. After centrifugation $\left(16,000 \times g\right.$ for $10 \mathrm{~min}$ at $\left.4^{\circ} \mathrm{C}\right)$ the supernatant containing the solubilized receptors was incubated at $4^{\circ} \mathrm{C}$ with anti-InsP $\mathrm{P}_{3} \mathrm{R}-\mathrm{I}$ (affinity purified from rabbit polyclonal antiserum directed against the $19 \mathrm{C}$-terminal residues of the mouse Ins $\mathrm{P}_{3} \mathrm{R}-\mathrm{I}$ ) for $1 \mathrm{~h}$, and then for an additional $12-24 \mathrm{~h}$ with protein A-Sepharose beads. The immune complexes were then isolated by centrifugation $(500 \times g$ for $2 \mathrm{~min})$ and washed three times with ice-cold PBS. The pellet of beads was then resuspended in sample buffer, and the protein was analyzed by SDS-PAGE.

When immunoprecipitating the receptor from cultured cells, the cells were harvested with HBSS (Invitrogen, Carlsbad, CA) and centrifuged at $750 \times g$ for $3 \mathrm{~min}$ at $4^{\circ} \mathrm{C}$. The cells were then incubated in lysis buffer, and the procedure described above was followed from that point on.

To partially purify the InsP ${ }_{3} \mathrm{R}-\mathrm{I}$ from mouse cerebella, tissue was solubilized in 1\% CHAPS (3-[(3-cholamidopropyl)dimethylammonio]-1propanesulfonate), and then this mixture was passed over a heparin affinity column as described previously (Thrower et al., 2003).

Culture and treatments of SH-SY5Y and DT40 B cells. SH-SY5Y cells were cultured in a 1:1 mixture of F-12 Ham's and Minimum Essential Medium, supplemented with $10 \%$ fetal bovine serum, $1 \%$ Minimum Essential Medium nonessential amino acids, and penicillin/streptomycin (Invitrogen). DT40 B cells were grown in RPMI 1640 supplemented with $10 \%$ fetal calf serum, $0.05 \mathrm{~mm} 2$-mercaptoethanol, $1 \%$ chicken serum, glutamine, and penicillin/streptomycin. Cells were cultured in a watersaturated atmosphere at $37^{\circ} \mathrm{C}$ and $5 \% \mathrm{CO}_{2}$. To induce an increase in $O$-GlcNAc, $n$-acetylglucosamine (GlcNAc) or O-(2-acetamido-2-deoxyD-glucopyranosylidene)amino- $N$-phenylcarbamate (PUGNAc) (kindly provided by G. W. Hart, Johns Hopkins University, Baltimore, MD) was added to the growth medium. PUGNAc was added at a final concentration of $200 \mu \mathrm{M}$ for $24 \mathrm{~h}$. GlcNAc was added at a final concentration of 8 $\mathrm{mm}$ for $72 \mathrm{~h}$ or with $8 \mathrm{~mm}$ mannitol as an osmotic protector.
Cerebellar and cellular microsomal preparation. Mouse or rat cerebella (Pel-Freez Biologicals) were homogenized using a Teflon-glass homogenizer in a homogenization buffer containing $250 \mathrm{~mm}$ sucrose, $5 \mathrm{~mm}$ HEPES/KOH, pH 7.4, 1 mм EGTA, 1 mм DTT, and protease inhibitors. The homogenate was then centrifuged at $1000 \times g$ for $5 \mathrm{~min}$ at $4^{\circ} \mathrm{C}$. The supernatant was saved and the pellet was resuspended in homogenization buffer and centrifuged again at $1000 \times g$ for $5 \mathrm{~min}$. The pellet was then discarded, and the pooled supernatants were centrifuged at $8000 \times$ $g$ for $10 \mathrm{~min}$ at $4^{\circ} \mathrm{C}$. The pellet was discarded, and the supernatant was centrifuged at $100,000 \times g$ for $75 \mathrm{~min}$. The final pellet was resuspended in homogenization buffer without EGTA and snap frozen in liquid nitrogen.

When preparing microsomes from cells, the cells were homogenized by passage through a 27 gauge needle. Then, the procedure described above was followed starting with the centrifugation at $8000 \times g$ for 10 min.

Western blot analysis. Protein samples were resolved by SDS-PAGE and transferred to a polyvinylidene difluoride membrane. The blots were then incubated overnight at $4^{\circ} \mathrm{C}$ with monoclonal antibodies that recognized the O-linked sugar bond; RL2 (isotype IgG1 from Affinity BioReagents, Golden, CO) or CTD 110.6 (isotype IgM from Covance, Richmond, CA). After washing, blots were incubated for $1 \mathrm{~h}$ at room temperature with HRP-linked goat anti-mouse antibody (Bio-Rad, Hercules, CA). Blots were then visualized using ECL (Pierce Biotechnology, Rockford, IL). Blots to be reprobed were previously stripped of antibodies using Re-Blot Plus kit (Chemicon International, Temecula, CA). One hour incubation at room temperature with polyclonal antibodies that recognized InsP ${ }_{3} \mathrm{R}-\mathrm{I}$ (Johenning et al., 2002) was followed by washing and incubation for $1 \mathrm{~h}$ at room temperature with HRP-linked goat antirabbit antibody (Bio-Rad). ECL was again used to visualize the blot. In some cases, the receptor was identified before the $O$-linked sugar bond; the order of visualization did not alter the results.

Removal of N-linked sugars or O-GlcNAc. Heparin-purified $\mathrm{InsP}_{3} \mathrm{R}-\mathrm{I}$ was treated with $\mathrm{N}$-glycosidase F, endoglycosidase $\mathrm{H}$ (New England BioLabs, Beverly, MA), or recombinant $O$-GlcNAcase $(\beta-N$-acetylglucosaminidase; product no. A6805; Sigma, St. Louis, MO) following the manufacturer's protocol. The ability to remove $O$-linked sugars was assessed by examining the treated samples with antibodies that recognized the $O$-linked sugar bond as described above (see Western blot analysis).

Preparation of mouse cerebellar cytosol. Cerebellar cytosol was isolated by homogenization and centrifugation as described previously (Marshall et al., 2003). Briefly, mouse cerebella were homogenized in ice-cold buffer consisting of $250 \mathrm{~mm}$ sucrose, $10 \mathrm{~mm}$ Tris, $1 \mathrm{~mm} \mathrm{MgCl}_{2}, \mathrm{pH} 7.6$, and protease inhibitors. The homogenate was then centrifuged at $600 \times$ $g$ for $10 \mathrm{~min}$. The pellet was discarded, and the supernatant was centrifuged at 20,000 $\times g$ for 10 min to obtain the crude cytosol. The cytosol was then desalted by polyethylene glycol (PEG) precipitation to increase the OGT activity of the sample. The cytosol was mixed with 2 vol of $30 \%$ ice-cold PEG solution ( $25 \mathrm{~mm}$ HEPES, $10 \mathrm{mM} \mathrm{MgCl}_{2}$, pH 7.2), and after being vortexed, the sample was centrifuged at $20,000 \times g$ for $20 \mathrm{~min}$ to precipitate proteins. The supernatant was discarded, and the pellet was resuspended in transferase assay buffer containing $25 \mathrm{~mm}$ HEPES, $10 \mathrm{~mm}$ $\mathrm{MgCl}_{2}$, and 1 mM EDTA, pH 7.

Single-channel recordings. Ins $\mathrm{P}_{3} \mathrm{R}-\mathrm{I}$ from cerebella microsomes were incorporated into planar lipid bilayers and recorded as described previously (Bezprozvanny et al., 1991; Thrower et al., 2003). The experiments were performed with a $250 \mathrm{~mm}$ HEPES-Tris solution, $\mathrm{pH}$ 7.35 , on the cis- and a $250 \mathrm{~mm}$ HEPES, $53 \mathrm{~mm} \mathrm{Ba}(\mathrm{OH})_{2}$ solution, $\mathrm{pH}$ 7.35 , on the trans-side of the bilayer ( $1 \mathrm{ml}$ chamber). For the $\mathrm{InsP}_{3} \mathrm{R}-\mathrm{I}$, single-channel activity was recorded in the presence of $0.5 \mathrm{~mm}$ ATP, 2 $\mu \mathrm{M} \mathrm{InsP_{3 }}, 8 \mu \mathrm{M}$ ruthenium red, and $0.3 \mu \mathrm{M}$ free $\mathrm{Ca}^{2+}$ on the cytoplasmic side of the InsP $_{3} \mathrm{R}$ (cis-side of the bilayer; $1 \mathrm{ml}$ chamber), unless otherwise specified. For the RyR, single-channel activity was recorded in the presence of $0.5 \mathrm{~mm}$ ATP and $0.3 \mu \mathrm{M}$ free $\mathrm{Ca}^{2+}$, but in the absence of $\mathrm{InsP}_{3}$ (which activates the $\mathrm{InsP}_{3} \mathrm{R}$ ) and ruthenium red (which blocks RyR). To elicit channel de-O-GlcNAcylation, a mixture of $4 \mu \mathrm{l}$ of $O$-GlcNAcase (Sigma) plus $1 \mu \mathrm{l}$ of $5 \times$ manufacturer reaction buffer was added directly to the cis-side of the bilayer without stirring. To elicit $O$-GlcNAcylation of the channel, a mixture of $1 \mu \mathrm{l}$ of 
UDP-GlcNAc plus $4 \mu \mathrm{l}$ of desalted cerebella cytosol was added directly over the membrane at the cis-side. After $1 \mathrm{~min}$, the reactions were stopped by stirring for $30 \mathrm{~s}$. Experiments were recorded under voltage-clamp conditions, the data were amplified (BC-525C; Warner Instrument, Hamden, CT), filtered at $1 \mathrm{kHz}$, digitized, and directly transferred to a computer. The data were acquired and analyzed with pClamp (Molecular Devices, Union City, CA). At least 3 min of recordings at each condition in each experiment were used for calculation of open probability, open and closed times.

Calcium imaging of SH-SY5Y cells. SH-SY5Y cells were plated on 22 $\mathrm{mm}^{2}$ glass coverslips, at $3-8 \times 10^{5}$ cells per well of a six-well plate, and grown overnight. Cultures were supplemented for $72 \mathrm{~h}$ with $20 \mathrm{~mm}$ mannitol, $8 \mathrm{~mm}$ GlcNAc, or $20 \mathrm{~mm}$ glucose, as indicated.

Coverslips were incubated for $30 \mathrm{~min}$ in HEPES-buffered saline (HBS) containing $130 \mathrm{~mm} \mathrm{NaCl}, 5 \mathrm{~mm} \mathrm{KCl}, 1.25 \mathrm{~mm} \mathrm{CaCl}_{2}, 1.2 \mathrm{~mm} \mathrm{KH}_{2} \mathrm{PO}_{4}, 1$ mm $\mathrm{MgSO}_{4}, 20 \mathrm{~mm}$ HEPES, $6.9 \mathrm{~mm}$ glucose, $\mathrm{pH}$ 7.4, with $\mathrm{NaOH}$, supplemented with $6 \mu \mathrm{M}$ fluo-4 AM (Invitrogen). Cells were washed with HBS, and placed in an imaging chamber (Warner Instrument) perfused with HBS on the stage of a Nikon (Tokyo, Japan) Diaphot fluorescence microscope. Fluo- 4 was illuminated through a $40 \times$ air objective from an $\mathrm{Hg}$ arc lamp and emission detected through a GFP (green fluorescent protein) filter cube to a cooled CCD camera (NeuroCCD-SM256; Red Shirt Imaging, Decatur, GA). After a baseline was established in HBS, $\mathrm{InsP}_{3}$-dependent $\mathrm{Ca}^{2+}$ release was stimulated by perfusion of MgATPcontaining HBS, as indicated, to the chamber. Throughout fluo-4 loading and perfusion, HBS was supplemented with $20 \mathrm{~mm}$ mannitol (control), $8 \mathrm{~mm}$ GlcNAc, or $20 \mathrm{~mm}$ glucose (26.9 mm total), as indicated.

Data were collected using Neuroplex 7.0 (Red Shirt Imaging) at $1 \mathrm{~Hz}$ and analyzed using IGOR Pro 5.0. Cells were considered to have responded to ATP if $\Delta F / F_{\mathrm{o}}$ was $>0.1$ after stimulation. Data are displayed as mean $\pm \mathrm{SE}$.

Cerebellar slice preparation and electrophysiological recording of slices. Slices (180 $\mu \mathrm{m}$ thick) were prepared from the vermis of cerebella taken from rats aged 11-15 d. Interneurons of the cerebellar molecular layer (MLIs) were identified as described previously (Llano and Gerschenfeld, 1993). During recordings, the slices were perfused $(1.5 \mathrm{ml} / \mathrm{min})$ with a saline solution containing $125 \mathrm{~mm} \mathrm{NaCl}, 2.5 \mathrm{~mm} \mathrm{KCl}, 1.25 \mathrm{~mm} \mathrm{NaH}_{2} \mathrm{PO}_{4}$, $26 \mathrm{~mm} \mathrm{NaHCO}_{3}, 2 \mathrm{~mm} \mathrm{CaCl}_{2}, 1 \mathrm{~mm} \mathrm{MgCl}_{2}$, and $10 \mathrm{~mm}$ glucose, equilibrated with a $95 \% \mathrm{O}_{2} / 5 \% \mathrm{CO}_{2}$ mixture, $\mathrm{pH}$ 7.3. All experiments were performed at room temperature. Whole-cell recordings were performed with an intracellular recording solution containing the following (in $\mathrm{mm}$ ): $140 \mathrm{~K}$-gluconate, $5.4 \mathrm{KCl}, 4.1 \mathrm{MgCl}_{2}$, 9.9 HEPES-K, 0.36 Na-GTP, and 3.6 Na-ATP, pH 7.3. MLIs were held in whole-cell recording for $<1$ min using the above intracellular recording solution, supplemented with $200 \mu \mathrm{M} \mathrm{K}{ }^{+}$salt of Oregon Green 488 BAPTA-1 (OG1) (Invitrogen) and $400 \mu \mathrm{M}$ caged Ins $(1,4,5) \mathrm{P}_{3}$ (Calbiochem, La Jolla, CA). The patch pipette was then withdrawn, and fluorescence recording could begin after a few minutes of equilibration.

Ins $P_{3}$ uncaging and calcium imaging in cerebellar slices. Digital fluorescence images were obtained using an excitation-acquisition system from TILL Photonics (Planegg, Germany). Briefly, to excite fluorescence of the $\mathrm{Ca}^{2+}$ dye OG1, light from a 75 W Xenon lamp was focused on a scanning monochromator set at $488 \mathrm{~nm}$ and coupled, by a quartz fiber and a lens, to the microscope, equipped with a dichroic mirror and a high-pass emission filter centered at 505 and $507 \mathrm{~nm}$, respectively. Images were acquired by a Peltier-cooled CCD camera (IMAGO QE; $1376 \times 1040$ pixels; pixel size: $244 \mathrm{~nm}$ after $53 \times$ magnification and $2 \times 2$ binning) connected to a 12 bit A/D converter. Photolysis of D-myo-InsP $\mathrm{P}_{3} \mathrm{P} 4(5)$ 1-(2-nitrophenyl)ethyl ester (caged $\mathrm{InsP}_{3}$ ) was achieved using a pulsed xenon arc lamp (Till Photonics). A high intensity (0.5-5 ms duration; 80 J) discharge of UV light $(360 \pm 7.5 \mathrm{~nm}$ ) was reflected onto the plane of focus using a dichroic mirror and Olympus (Tokyo, Japan) $60 \times$ water immersion objective (numerical aperture, 0.9). Analysis of images was performed as described previously (Llano et al., 1997) using homemade routines within the IGOR programming environment (Wavemetrics, Lake Oswego, OR).

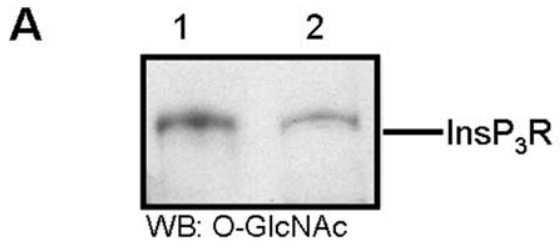

\section{B}
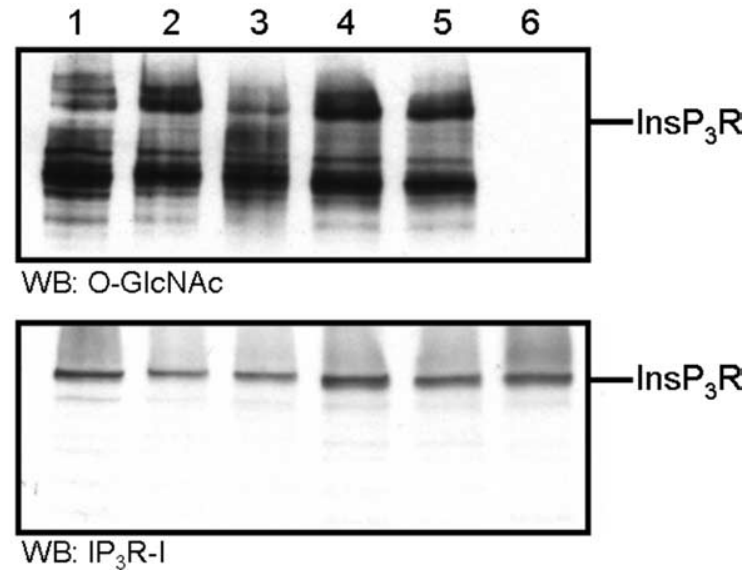

Figure 1. The Ins $\mathrm{P}_{3} \mathrm{R}-\mathrm{I}$ is $\mathrm{O}$-GICNAc modified. $\boldsymbol{A}$, Western blot analysis of Ins $\mathrm{P}_{3} \mathrm{R}-\mathrm{I}$ immunoprecipitated from mouse cerebellum (lane 1) or from SH-SY5Y cells (lane 2) and then probed with anti 0 -GICNAC. $B$, Heparin-purified InsP $\mathrm{R}$-I from mouse cerebellum was treated at $37^{\circ} \mathrm{C}$ with enzymes that remove $\mathrm{N}$-linked glycosylation or 0 -linked GICNAc as follows: lane $1,1 \mathrm{~h}$ incubation with no treatment; lane 2, 1 h incubation with $\mathrm{N}$-glycosidase F (PNGase F); lane 3, overnight incubation with PNGase F; lane 4, 1 h incubation with endoglycosidase $\mathrm{H}$ (Endo H); lane 5, overnight incubation with Endo $\mathrm{H}$; lane 6, $1 \mathrm{~h}$ incubation with $\mathrm{O}-\mathrm{GlcNAcase}$. The membrane was first probed with anti-0-GICNAC. This antibody was then removed, and the membrane was reprobed with anti-InsP $\mathrm{P}_{3} \mathrm{R}-\mathrm{I}$. WB, Western blot.

\section{Results}

\section{The InsP $\mathrm{P}_{3} \mathrm{R}$-I is modified by $\mathrm{O}$-GlcNAc}

To determine whether $O$-GlcNAcylation is involved in regulation of the Ins $\mathrm{P}_{3} \mathrm{R}-\mathrm{I}$ channel, we first established that the $\operatorname{Ins}_{3} \mathrm{R}-\mathrm{I}$ is

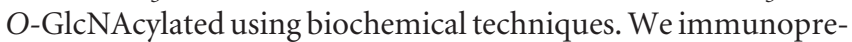
cipitated the InsP ${ }_{3} \mathrm{R}$-I from mouse cerebella and from SH-SY5Y cells using an antibody produced to recognize the $\mathrm{InsP}_{3} \mathrm{R}-\mathrm{I}$ (Johenning et al., 2002). Western blot analysis was performed using an antibody that recognizes O-GlcNAcylated proteins [RL2 (Snow et al., 1987)]. The InsP ${ }_{3} \mathrm{R}-\mathrm{I}$ band was identified from both samples by RL2 indicating that the receptor is $\mathrm{O}$-GlcNAcylated (Fig. 1A). This immunoreactivity was specifically inhibited in the presence of $0.3 \mathrm{M}$ GlcNAc (data not shown). Another antibody that recognizes GlcNAc in a $\beta$-O-glycosidic linkage to both serine and threonine, CTD110.6 (Comer et al., 2001), also identified Ins $\mathrm{P}_{3} \mathrm{R}-\mathrm{I}$ bands (data not shown).

Treatment of the InsP $\mathrm{P}_{3} \mathrm{R}$-I with $\mathrm{O}$-GlcNAcase removes anti-OGlcNAc immunoreactivity

To confirm that the immunoreactivity detected was attributable to $\mathrm{O}$-GlcNAcylation and not to $\mathrm{N}$-glycosylation, which is known to be present on the $\operatorname{Ins}_{3} \mathrm{R}-\mathrm{I}$ (Michikawa et al., 1994), we partially purified the $\mathrm{Ins}_{3} \mathrm{R}-\mathrm{I}$ by heparin affinity chromatography and treated it with $\mathrm{N}$-glycosidase $\mathrm{F}$, endoglycosidase $\mathrm{H}$, or $\mathrm{O}$-GlcNAcase. $\mathrm{N}$-Glycosidase $\mathrm{F}$ and endoglycosidase $\mathrm{H}$ remove oligosaccharides from $\mathrm{N}$-linked glycoproteins. After treating the purified proteins with $\mathrm{N}$-glycosidase F or endoglycosidase $\mathrm{H}$, Western blot analysis showed that the protein sample was still stained by RL2 (Fig. 1B, lanes 2-5). In contrast, treatment with 
A
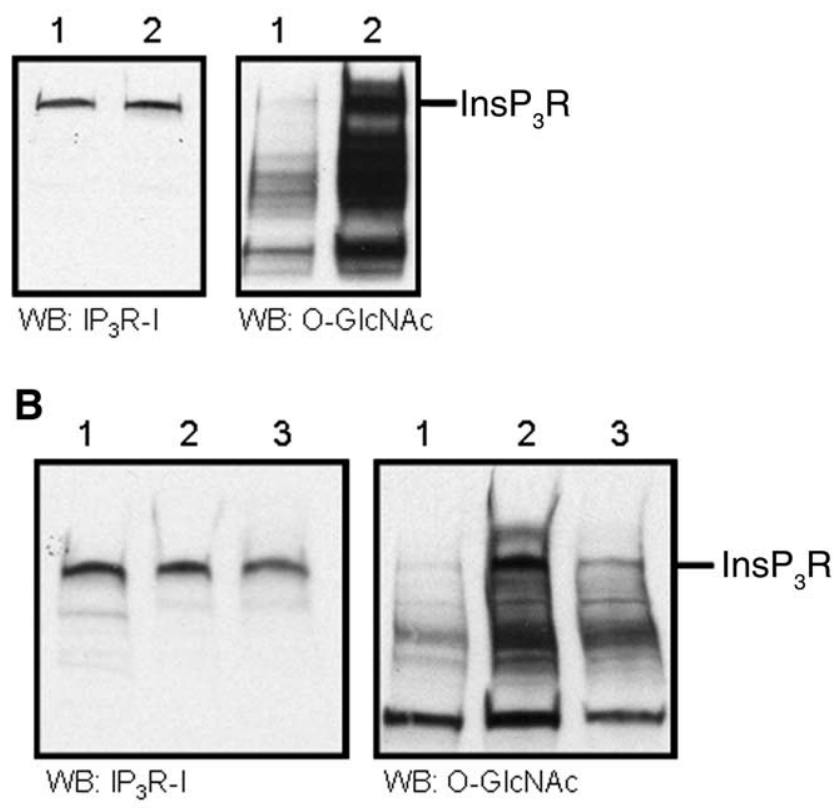

C

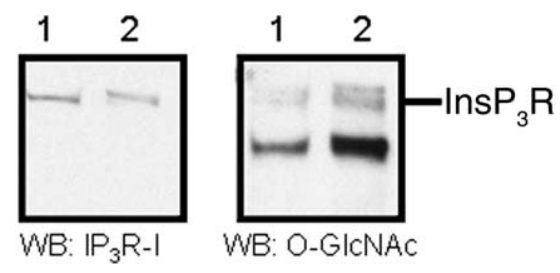

Figure 2. Ins $\mathrm{P}_{3} \mathrm{R}-\mathrm{O}$ O-GICNAcylation can be modulated in vivo. A, Microsomal preparation from SH-SY5Y cells grown at $37^{\circ} \mathrm{C}$ as follows: lane 1, no treatment; lane 2, incubation with 200 $\mu \mathrm{M}$ PUGNAc for $24 \mathrm{~h} . \boldsymbol{B}$, Microsomes were prepared from DT $40 \mathrm{~B}$ cells grown at $37^{\circ} \mathrm{C}$ as follows: lane 1, no treatment; lane 2, incubation with $200 \mu \mathrm{M}$ PUGNAc for $24 \mathrm{~h}$; lane 3, cells were grown in control conditions but the microsomal preparation was performed with $50 \mathrm{~mm}$ GlcNAc present in the homogenization buffer. $C$, InsP $\mathrm{R}$-I was immunoprecipitated from DT40 B cells grown at $37^{\circ} \mathrm{C}$ as follows: lane 1 , no treatment; lane 2 , incubation with $8 \mathrm{~mm} \mathrm{GICNAc} \mathrm{for} 72 \mathrm{~h}$. For $A-C$, the membrane was first probed against Ins $P_{3} R-I$ and then reprobed against $0-G \mid c N A c$. WB, Western blot.

$O-G l c N A c a s e$ removed the anti-O-GlcNAc immunoreactivity (Fig. $1 \mathrm{~B}$, lane 6). The anti-O-GlcNAc antibody was removed and the membrane was reprobed with anti-InsP ${ }_{3} \mathrm{R}$-I showing homogeneous Ins $\mathrm{P}_{3} \mathrm{R}-\mathrm{I}$ staining in all lanes (Fig. $1 \mathrm{~B}$ ).

\section{$O$-GlcNAc modification of the Ins $\mathrm{P}_{3} \mathrm{R}-\mathrm{I}$ can be modulated in vivo}

When cells were incubated with the O-GlcNAcase inhibitor PUGNAc or with the hexosamine pathway intermediate GlcNAc, there was an increase in $\mathrm{O}$-GlcNAcylation of numerous proteins (Haltiwanger et al., 1998). We treated SH-SY5Y and DT40 B cells with PUGNAc, prepared microsomes, and analyzed the $O-G l c N A c$ level with Western blot analysis. Initial staining with anti-InsP ${ }_{3} \mathrm{R}-\mathrm{I}$ showed equivalent levels of protein on the sample from SH-SY5Y cells in control conditions and from cells incubated with PUGNAc (Fig. $2 A$ ). The membrane was then stripped of antibodies and reprobed with anti-O-GlcNAc. PUGNAc increased $O-G l c N A c y l a t i o n$ of many microsomal proteins including the Ins $\mathrm{P}_{3} \mathrm{R}$-I. This effect was also seen when examining the effects in DT40 B cells (Fig. 2 B). Additionally, microsomes from DT40 B cells grown under control conditions were prepared with homogenization buffer supplemented with GlcNAc. It was found that this treatment also increased the level of $O$-GlcNAcylation (Fig. $2 \mathrm{~B}$ ), suggesting that endogenous $\mathrm{O}$-GlcNAcase can remove GlcNAc from proteins during microsomal preparation. The addition of GlcNAc to the homogenization buffer provided excess substrate that was able to compete with the GlcNAc attached to proteins for binding to $O$-GlcNAcase, resulting in less removal of GlcNAc from proteins.

To confirm that the increase in $O$-GlcNAc immunoreactivity detected at the molecular weight of the $\mathrm{InsP}_{3} \mathrm{R}$-I was attributable to increased $\mathrm{O}$-GlcNAcylation of the $\mathrm{InsP}_{3} \mathrm{R}-\mathrm{I}$, we immunoprecipitated the Ins $\mathrm{P}_{3} \mathrm{R}$-I from DT40 B cells grown in media supplemented with GlcNAc. Initial staining with anti-InsP ${ }_{3} \mathrm{R}-\mathrm{I}$ showed equivalent levels of receptor on the sample from DT40 B cells in control conditions and from cells incubated with GlcNAc (Fig. $2 C$, left panel). After blotting for $\operatorname{Ins}_{3} \mathrm{R}-\mathrm{I}$, the membrane was stripped of antibodies and reprobed for O-GlcNAc. Under control conditions, the Ins $\mathrm{P}_{3} \mathrm{R}-\mathrm{I}$ is $\mathrm{O}-\mathrm{GlcNAcylated}$. The presence of multiple high molecular weight bands on the blot reflects the observation that the receptor is easily degraded and that it forms multimers under many conditions (Fig. $2 C$, right panel, lane 1). Incubation with GlcNAc elevated the level of $O$-GlcNAcylation of the receptor (Fig. $2 C$, right panel, lane 2). The immunoreactivities detected for the InsP $\mathrm{P}_{3} \mathrm{R}$-I were measured by densitometry, and the $\mathrm{O}$-GlcNAc signal was normalized with the $\mathrm{InsP}_{3} \mathrm{R}-\mathrm{I}$ blot. Incubation with GlcNAc produced an almost threefold increase of the relative InsP $_{3} \mathrm{R}-\mathrm{I} O-$ GlcNAcylation from $0.046 \pm 0.009$ to $0.13 \pm 0.016(n=3 ; p<0.009$ compared with control conditions).

\section{Addition and removal of $O$-GlcNAc have reciprocal functional effects on the Ins $P_{3} R-I$ channel}

To study the modulation of the Ins $\mathrm{P}_{3} \mathrm{R}-\mathrm{I}$ by $\mathrm{O}$-GlcNAcylation, we incorporated mouse cerebellar $\mathrm{InsP}_{3} \mathrm{R}-\mathrm{I}$ into planar lipid bilayers. Under control conditions, the presence of $0.5 \mathrm{~mm}$ ATP, 0.3 $\mu \mathrm{M}$ free $\mathrm{Ca}^{2+}$, and $8 \mu \mathrm{M}$ ruthenium red (which blocks $\mathrm{RyR}$ ) on the cytosolic (cis-) side of the bilayer elicited no channel activity (Fig. 3A, first trace). Addition of $2 \mu \mathrm{M} \mathrm{InsP}_{3}$ elicited channel activity (Fig. $3 A$, second trace) with an open probability of $1.4 \pm$ $0.3 \%(n=4)$. To study the functional effect of de-OGlcNAcylation of the $\mathrm{InsP}_{3} \mathrm{R}-\mathrm{I}$, we applied $\mathrm{O}$-GlcNAcase directly to the bilayer on the cis-side. Removal of the O-GlcNAc modification induced an increase of more than threefold in the open probability (Fig. $3 A$, third trace), to $5 \pm 1 \%(n=4 ; p<0.03$ compared with control conditions) (Fig. $3 C$ ). As a control, the solution containing $\mathrm{O}$-GlcNAcase was boiled to denature it before addition to the bilayer chamber; no change in channel activity was detected under these conditions (data not shown).

To study the functional effect of O-GlcNAcylation on the InsP $_{3} \mathrm{R}-\mathrm{I}$, we isolated mouse cerebellar cytosol (supplemental Fig. 1, available at www.jneurosci.org as supplemental material) (Marshall et al., 2003) and used it as a source of OGT to modify the InsP $\mathrm{P}_{3} \mathrm{R}-\mathrm{I}$ inserted into planar lipid bilayers. Although OGT has been cloned and partially characterized (Kreppel et al., 1997; Lubas and Hanover, 2000), the recombinant enzyme does not retain a high level of activity for in vitro use. Therefore, brain cytosol has been used as a reasonable source of OGT activity. Addition of $0.5 \mathrm{~mm}$ ATP and $0.3 \mu \mathrm{M}$ free $\mathrm{Ca}^{2+}$ to the cis-side of the bilayer elicited no channel activity (Fig. $3 B$, first trace). Addition of $2 \mu \mathrm{M}$ InsP $_{3}$ elicited channel openings with an open probability of $1.5 \pm 0.4 \%(n=4)$ (Fig. $3 B$, second trace). Addition of cerebellar cytosolic extract and the GlcNAc donor UDP-GlcNAc directly to the lipid bilayer on the cis-side induced a dramatic 
A

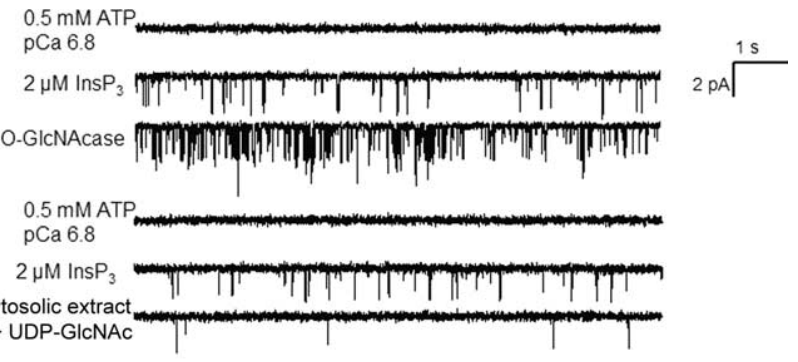

C

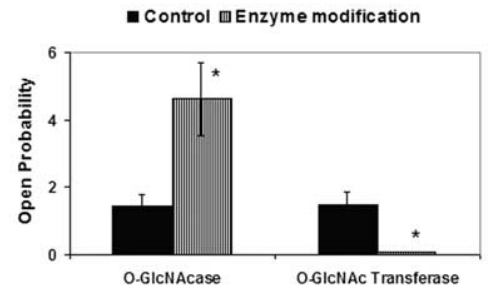

Figure 3. Addition and removal of 0 -GICNAc have reciprocal functional effects on the Ins $\mathrm{P}_{3} \mathrm{R}$-I channel inserted into lipid bilayers. Each trace corresponds to $10 \mathrm{~s}$ of current recordings from the same experiment. Openings are defined as downward deflections from the baseline. $A$, 0 -GIcNAcase activates the $\operatorname{Ins}_{3} \mathrm{R}$-I. Trace 1 , Addition of $0.5 \mathrm{~mm} \mathrm{ATP}$ and $0.3 \mu \mathrm{m}$ free $\mathrm{Ca}^{2+}$ elicits no channel activity. Trace 2, Addition of $2 \mu \mathrm{m}$ Ins $\mathrm{P}_{3} \mathrm{R}-\mathrm{I}$ elicits channel activity with an open probability of $1.4 \%$. Trace 3 , Removal of the 0 -GICNAc modification with addition of O-GIcNAcase increases the open probability to 5\%. B, Increased 0 -GlcNAcylation inhibits the InsP $\mathrm{P}_{3} \mathrm{R}$-I. Trace 1 , Addition of $0.5 \mathrm{~mm}$ ATP and $0.3 \mu \mathrm{m}$ free $\mathrm{Ca}^{2+}$ elicits no channel activity. Trace 2 , Addition of $2 \mu \mathrm{m}$ Ins $\mathrm{P}_{3} \mathrm{R}$-I elicits channel activity with an open probability of $1.5 \%$. Trace 3 , Application of cerebellar cytosolic extract and UDP-GICNAC directly to the bilayer adds the 0 -GICNAc modification to the channel, reducing the open probability to $0.06 \%$. C, Mean open probability and SEM for each bilayer condition. ${ }^{*} p<0.05$.

reduction in channel activity (Fig. $3 B$, third trace), to $0.08 \pm$ $0.01 \%$ ( $n=4 ; p<0.02$ compared with control conditions) (Fig. $3 C)$. As a control, UDP-GlcNAc without cerebella cytosol was added to the bilayer chamber; no change in channel activity was observed under these conditions (data not shown). To show the specificity of the modulation by $O$-GlcNAcylation, the addition of $O$-GlcNAcase directly to the cis-side of bilayers containing the RyR did not induce a detectable change in RyR channel activity (supplemental Fig. 2, available at www.jneurosci.org as supplemental material).

These reciprocal functional effects were also demonstrated by consecutive addition of cytosolic extract and UDP-GlcNAc followed by $O-G l c N A c a s e$ to the same channel. Addition of $2 \mu \mathrm{M}$ Ins $_{3}$ in the presence of $0.5 \mathrm{~mm}$ ATP and $0.3 \mu \mathrm{M}$ free $\mathrm{Ca}^{2+}$ elicits the opening of a channel with an open probability of $1.9 \pm 0.6 \%$ $(n=2)$ (Fig. 4, first and second traces). OGT modification of the channel was produced by addition of cytosolic extract and UDPGlcNAc directly to the lipid bilayer reducing the channel open probability to $0.1 \pm 0.02 \%(n=2)$ (Fig. 4 , third trace). The channel was then modified by $O$-GlcNAcase, which removed $O$-GlcNAc from the receptor and increased the open probability to $0.28 \pm 0.05 \%(n=2)$ (Fig. 4 , fourth trace). We believe the open probability did not return all the way to control values because the single addition of $O$-GlcNAcase to the bilayer was not able to remove all of the $O$-GlcNAc. It was not possible to make a second addition of $O$-GlcNAcase because of bilayer breakage.

Incubation with GlcNAc decreases whole-cell $\mathrm{Ca}^{2+}$ transients To investigate whether $\mathrm{O}-\mathrm{GlcNAcylation}$ of the $\mathrm{InsP}_{3} \mathrm{R}-\mathrm{I}$ also regulated the release of $\mathrm{Ca}^{2+}$ in intact cells, we treated SH-SY5Y cells for $72 \mathrm{~h}$ with $8 \mathrm{~mm}$ GlcNAc to increase O-GlcNAcylation of the $\mathrm{InsP}_{3} \mathrm{R}-\mathrm{I}$ (Fig. 5) and exposed them to extracellular ATP, known to stimulate Ins $_{3}$ production via $\mathrm{P}_{2 \mathrm{Y}}$ purinergic receptors. At 50 nм ATP stimulation, $86 \%$ of control cells responded, compared with $53 \%$ of GlcNAc-treated cells. At 100 nM ATP stimulation, all control cells responded, compared with only $75 \%$ of GlcNAc treated, whereas all cells of both groups responded with $\Delta F / F_{\mathrm{o}}>0.1$ after $1 \mu \mathrm{M}$ ATP stimulation (Fig. $5 B$ ). This suggests that, at submaximal levels of $\mathrm{InsP}_{3}$ generation, pretreatment with GlcNAc increases the threshold for $\mathrm{InsP}_{3}$-induced $\mathrm{Ca}^{2+}$ release, but that all treated cells are capable of responding, given sufficient stimulation.

Looking at the cells that did respond under each condition, we see that the responses are different. With 50 or $100 \mathrm{~nm}$ ATP stimulation, control and GlcNAc-treated cells respond similarly, whereas at maximal stimulation control cells exhibit a greater peak height than GlcNAc treated $(0.84 \pm 0.01$ vs $0.68 \pm 0.01 ; p<$ $10^{-20}$ ) (Fig. $5 C$ ). Combined with the data above, we conclude that GlcNAcylation leads to both a decrease in the sensitivity of cells to Ins $\mathrm{P}_{3}$ and to a reduced maximal $\mathrm{Ca}^{2+}$ response because of $\mathrm{Ins}_{3}$ stimulation. This suggests an effect at the cell level consistent with a decrease in Ins $\mathrm{P}_{3} \mathrm{R}$ open probability as determined for single channels.

UDP-GlcNAc is generated physiologically through the hexosamine pathway, which branches off from the glycolytic intermediate fructose-6-phosphate. As such, the physiological concentration of UDP-GlcNAc is controlled by the glucose uptake of a cell, and it stands to reason that a high glucose environment can lead to increased O-GlcNAcylation of proteins (Robinson et al., 1995). To investigate the role of this more physiological agonist, cells were incubated for $72 \mathrm{~h}$ in $26.9 \mathrm{~mm}$ glucose $(6.9 \mathrm{~mm}$ in medium, supplemented with $20 \mathrm{~mm}$ ) to induce increased O-GlcNAcylation. Similar to GlcNAc-treated cells, fewer highglucose-treated cells responded to low levels of ATP stimulation compared with control, whereas all cells responded at high agonist concentration (Fig. $5 B$ ). In addition, the effect on peak height at different concentrations of ATP was even more pronounced for high-glucose-treated cells, with the mean peak height of responding cells only one-half that of control cells at $100 \mathrm{~nm} \mathrm{ATP}$ stimulation $(0.20 \pm 0.01$ vs $0.49 \pm 0.03)$ (Fig. $5 C)$.

\section{Addition of UDP-GlcNAc decreases calcium transients after uncaging $\operatorname{Ins} \mathrm{P}_{3}$}

To verify that the effect of GlcNAc on intact cell $\mathrm{Ca}^{2+}$ signaling was attributable to $\mathrm{InsP}_{3} \mathrm{R} \mathrm{Ca}^{2+}$ release, we tested the effect of GlcNAc addition on the responses to release of $\mathrm{InsP}_{3}$ in cerebellar interneurons. First, it was necessary to show that uncaging of $\mathrm{InsP}_{3}$ in these cells was capable of inducing $\mathrm{Ca}^{2+}$ release. Cells were preloaded with caged $\mathrm{InsP}_{3}$ and the $\mathrm{Ca}^{2+}$ indicator OG-1 (Fig. 6). After a 4 min equilibration period, a UV flash was produced every $3 \mathrm{~min}$ to release $\mathrm{InsP}_{3}$, and $\mathrm{Ca}^{2+}$ transients were monitored. The magnitude and shape of the responses were stable, diminishing by $<20 \%$ over 19 min (Fig. $6 B, C$ ). The ability of uncaged $\mathrm{InsP}_{3}$ to induce $\mathrm{Ca}^{2+}$ release was inhibited by the addition of the $\mathrm{InsP}_{3} \mathrm{R}$ inhibitor 2-APB at $20 \mu \mathrm{M}$ (data not shown).

To test the effect of $O-G l c N A c y l a t i o n$ on the response to uncaging of Ins $\mathrm{P}_{3}$, UDP-GlcNAc $(10 \mathrm{~mm})$ was added to the pipette during the preloading stage of the experiments. The first response after equilibration (at 4 min after introduction of the compound) was already reduced; the GlcNAc loaded cells showed a $72 \%$ reduction in the response to uncaging of $\operatorname{Ins}_{3}(n=6 ; p<0.001)$. The response to uncaging of $\mathrm{InsP}_{3}$ at 4 and $7 \mathrm{~min}$ was stable in both the control cells and in cells loaded with GlcNAc (Fig. 6C). Subsequent responses to uncaging of $\mathrm{Ins}_{3}$ in control cells declined by $\sim 20 \%$ in part because the amount of caged $\operatorname{InsP}_{3}$ was 
decreasing in the cell. In contrast, the responses to uncaging of $\mathrm{InsP}_{3}$ in GlcNAcloaded cells declined nearly to baseline (Fig. 6B, $)$ ), confirming a reduced sensitivity to $\mathrm{InsP}_{3}$ in GlcNAc-treated cells.

\section{Discussion}

In this study, we show for the first time that the $\mathrm{InsP}_{3} \mathrm{R}-\mathrm{I}$ is $\mathrm{O}-\mathrm{GlcNAcylated}$ and that modification by $\mathrm{O}-\mathrm{GlcNAcylation}$ has functional effects on the Ins $\mathrm{P}_{3} \mathrm{R}$-I channel. Addition of $O-G l c N A c$ decreases the probability of channel opening and removal of $O-G l c N A c$ increases channel activity, most likely by influencing the $\mathrm{InsP}_{3}$ dependence of the Ins $\mathrm{P}_{3} \mathrm{R}$. The open probability of the Ins $\mathrm{P}_{3} \mathrm{R}-\mathrm{I}$ inserted into lipid bilayers was increased threefold when $O$-GlcNAcase was added to remove Glc$\mathrm{NAc}$ from the channel. The RyR is also $O$-GlcNAcylated, but removal of $O$-GlcNAc does not change its open probability. We also studied the effect of O-GlcNAc modification on the ability of cerebellar interneurons to produce $\mathrm{InsP}_{3}$-dependent $\mathrm{Ca}^{2+}$ transients. We found that addition of UDP-GlcNAc decreased the ability of these cells to produce a $\mathrm{Ca}^{2+}$ transient when $\mathrm{InsP}_{3}$ was elevated, as predicted from the results obtained at the single-channel level. These results uncover a new mechanism of regulation of the $\mathrm{InsP}_{3} \mathrm{R}-\mathrm{I}$ channel that is specific to this family of intracellular $\mathrm{Ca}^{2+}$ release channel.

$\mathrm{Ins}_{3} \mathrm{R}-\mathrm{I}$ from several sources (mouse cerebella, SH-SY5Y cells, and DT-40 cells) were modified by GlcNAc. Both addition and removal of $O$-GlcNAc could be accomplished with the enzymes known to be present in the cytoplasm and nucleus (Kreppel et al., 1997; Gao et al., 2001). The reactions are specific to O-linked sugars: O-GlcNAc immunoreactivity was removed when the $\mathrm{InsP}_{3} \mathrm{R}$-I was treated with $\mathrm{O}$-GlcNAcase but not when it was treated with enzymes that remove oligosaccharides from $N$-linked glycoproteins (Fig. $1 B$ ). Additional support for the specificity is that neither addition of boiled O-GlcNAcase nor of UDP-GlcNAc alone altered channel activity.

Other studies have demonstrated that O-GlcNAcylation regulates protein function either by altering enzyme activity, protein-protein interactions, subcellular localization, or protein phosphorylation. O-GlcNAc modification of glycogen synthase results in the retention of the enzyme in a glucose 6-phosphatedependent state and contributes to the reduced activation of the enzyme in insulin resistance (Parker et al., 2003). O-GlcNAcylation of the activation domain of Sp1 blocks its in vitro and in vivo interactions with other $\mathrm{Sp} 1$ molecules and its transcriptional capability (Yang et al., 2001). Microtubuleassociated Tau proteins are also modified by phosphorylation and O-GlcNAcylation. An increase in Tau protein phosphorylation level correlates with a decrease in O-GlcNAcylation level and with a reduced transfer of Tau into the nucleus (Lefebvre et al., 2003).

To survive environmental, physiological, or chemical stress, cells must initiate signal transduction events that activate mechanisms that counteract apoptosis. Recent studies have found that conditions of stress generate a global increase in $\mathrm{O}$-GlcNAc protein modification and that increasing $O$-GlcNAc levels protects cells (Zachara et al., 2004; Zachara and Hart, 2006). It was also observed that $O$-GlcNAc regulates both the rate and extent of the stress-induced induction of heat shock proteins, providing a mo- lecular basis to the cellular protection produced by $O$-GlcNAc (Zachara et al., 2004). $\mathrm{Ca}^{2+}$-sensitive activation of caspases is an important pathway for the induction of apoptosis, and $\mathrm{InsP}_{3} \mathrm{R}$-Isensitive $\mathrm{Ca}^{2+}$ stores have been shown to play a role (Hajnoczky et al., 2000). Our observation that $O$-GlcNAcylated $\mathrm{InsP}_{3} \mathrm{R}-\mathrm{I}$ channels are low activity channels provides another possible explanation for how increased $O$-GlcNAcylation results in cellular protection against apoptosis.

Interestingly, an increase in $O$-GlcNAc level in myocardial cells has been associated with protection against stresses, such as ischemia and reperfusion, which lead to $\mathrm{Ca}^{2+}$ overload. In a study of whole heart models, GlcNAc pretreatment elevated protein $O$-GlcNAcylation resulting in a marked increase in tolerance to injury caused by ischemia/reperfusion, characterized by a decreased release of lactate dehydrogenase (a marker of tissue injury) and improved contractile function (Liu et al., 2006). The recent finding that increases in cytosolic $\mathrm{Ca}^{2+}$ produced by $\mathrm{InsP}_{3}$ generating agonists in cardiomyocytes are inhibited by increased O-GlcNAc levels (Nagy et al., 2006) is consistent with our observation that $\mathrm{O}-\mathrm{GlcNA}$ cylated $\mathrm{InsP}_{3} \mathrm{R}-\mathrm{I}$ channels are low activity channels. We also showed that $O$-GlcNAcylation of RyR does not regulate channel activity. In the failing human heart, expression of these two intracellular $\mathrm{Ca}^{2+}$ release channels is regulated in opposite directions, where RyR is downregulated and $\operatorname{InsP}_{3} \mathrm{R}-\mathrm{I}$ is upregulated (Go et al., 1995). Together, these results indicate that $\mathrm{Ca}^{2+}$ release through the $\mathrm{InsP}_{3} \mathrm{R}$-I plays an important role in the cardioprotection provided by GlcNAc against myocardial $\mathrm{Ca}^{2+}$ overload.

Diabetic cardiomyopathy is characterized by poor cardiac contractility linked to impaired sarcoplasmic reticulum $\mathrm{Ca}^{2+} \mathrm{cy}-$ cling, including reduced sarcoplasmic reticulum $\mathrm{Ca}^{2+}$ content, decreased diastolic $\mathrm{Ca}^{2+}$ uptake and systolic $\mathrm{Ca}^{2+}$ release. Two recent papers have documented these alterations of $\mathrm{Ca}^{2+}$ signaling in the diabetic cardiomyocyte and have linked them to increased levels of protein O-GlcNAcylation (Clark et al., 2003; Hu et al., 2005). It was shown in diabetic heart models that protein $O$-GlcNAcylation is increased in both type I and type II diabetes (Hu et al., 2005). Animals with streptozotocin-induced diabetes and hyperglycemia show a greatly increased concentration of the hexosamine metabolite UDP-GlcNAc (Robinson et al., 1995). Thus, under diabetic conditions, high UDP-GlcNAc leads to an increase in protein O-GlcNAcylation (Akimoto et al., 2000; Clark et al., 2003). Adenovirus-mediated overexpression of 

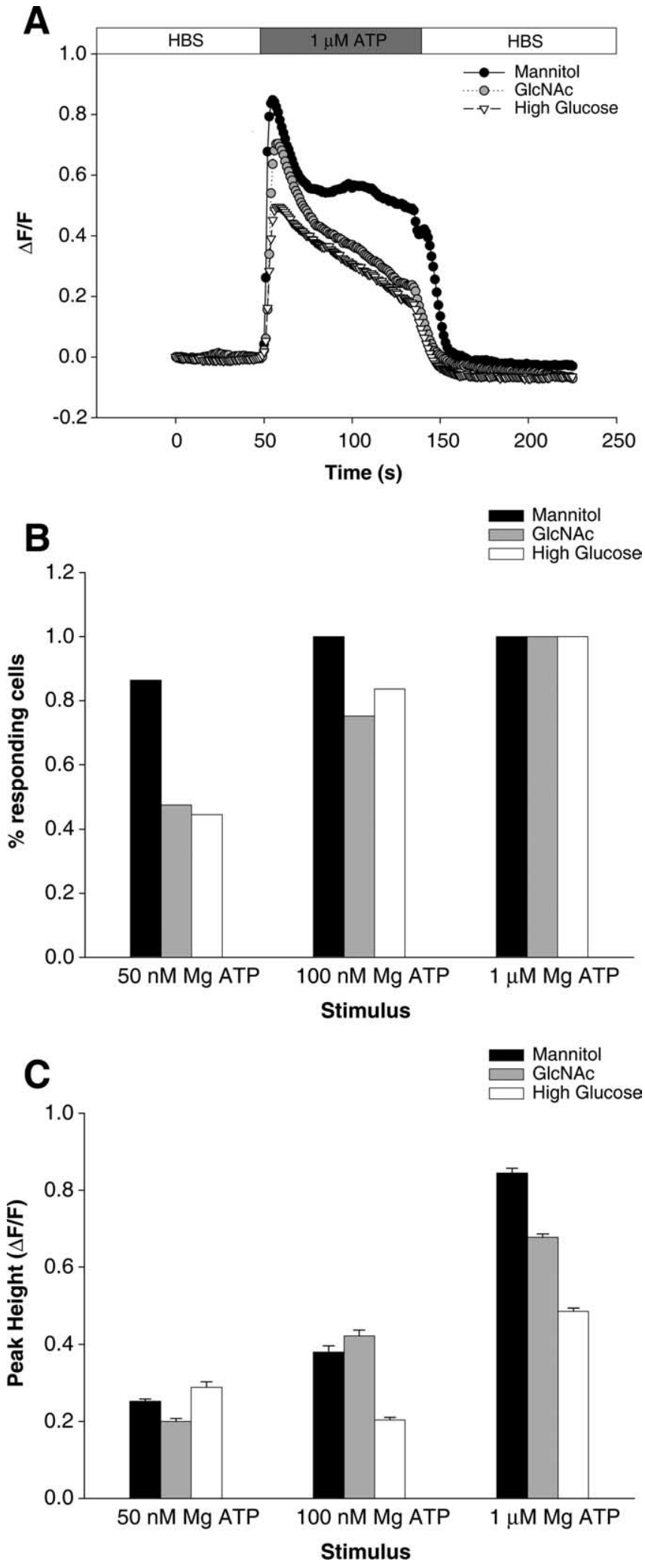

Figure 5. GlcNAc reduces whole-cell $\mathrm{Ca}^{2+}$ transients. $A$, Single traces show the time course of the $\mathrm{Ca}^{2+}$ response for mannitol-, GlcNAc-, or high-glucose-treated SH-SY5Y cells stimulated with $1 \mu \mathrm{m}$ ATP where indicated. $\boldsymbol{B}$, Percentage of cells responding to $50 \mathrm{~nm}, 100 \mathrm{~nm}$, or $1 \mu \mathrm{m}$ ATP application from each treatment group, as indicated. $C$, Peak height of response to ATP stimulation for each treatment group, as indicated. Data are displayed as mean \pm SEM.
$O$-GlcNAcase was shown to reduce cellular O-GlcNAcylation, enhance the diabetic cardiomyocyte transient, the sarcoplasmic reticulum $\mathrm{Ca}^{2+}$ loading, and improve contractile function (Hu et al., 2005). Our finding that increased O-GlcNAcylation of the Ins $\mathrm{P}_{3} \mathrm{R}$-I results in decreased $\mathrm{Ca}^{2+}$ release is consistent with the diabetes-induced reduction in systolic $\mathrm{Ca}^{2+}$ release and the enhancement of the diabetic cardiomyocyte transient resulting from $O-$ GlcNAcase overexpression.

Brain damage is a recognized complication of diabetes. Data from epidemiological studies suggest that diabetes is a risk factor for neurocognitive dysfunction (Launer, 2005). The pathophysiological basis of the dysfunction remains controversial with some studies identifying recurrent hypoglycemia as the primary cause of neuronal damage, whereas others associate these effects to chronic hyperglycemia (McNay et al., 2006; Wessels et al., 2006). To further complicate the issue, recent reports indicate that, although brain dysfunction has been consistently reported in many diabetic patients, the literature fails to find serious and progressive global cognitive impairment (Ryan, 2006; Wessels et al., 2006). In contrast, a recent study of the effect of recurrent hypoglycemia in cognitive function of a diabetic rat model concludes that recurrent hypoglycemia actually prevents the agerelated decline in hippocampus-associated cognitive function (McNay et al., 2006). The remarkable implication of these data is that diabetic-associated changes in brain structure and function exist and can be measured, although only subtle neurocognitive dysfunction has been detected. A neuronal protective process must contribute to the relative preservation of neurocognitive function in the presence of damaged tissue. The brain is one of the tissues with the highest expression levels of OGT and O-GlcNAcase (Haltiwanger et al., 1992; Gao et al., 2001). Protein $O$-GlcNAcylation is increased in both type I and type II diabetes (Hu et al., 2005). Diabetes causes a reduction in the amplitude of Ins $\mathrm{P}_{3}$-induced $\mathrm{Ca}^{2+}$ release in primary and secondary nociceptive neurons (Clark et al., 2003; Kruglikov et al., 2004). Because excessive cytosolic $\mathrm{Ca}^{2+}$ is a well known mediator of neuronal death, increased $\mathrm{O}$-GlcNAcylation of $\mathrm{InsP}_{3} \mathrm{R}$-I leading to low channel activity would provide protection against apoptosis and associated changes in brain structure and function.

Growing evidence implicates $\mathrm{Ca}^{2+}$ signaling disruptions in the etiology of neurodegenerative disorders like Alzheimer's disease $(\mathrm{AD})$. Most cases of $\mathrm{AD}$ are sporadic, but $\sim 10 \%$ are inherited (Thinakaran and Sisodia, 2006). Mutations in presenilins 1 and 2 account for $\sim 20-50 \%$ of these forms of familial AD (FAD) (Tandon and Fraser, 2002). Impaired $\mathrm{Ca}^{2+}$ homeostasis and exaggerated $\mathrm{InsP}_{3}$-mediated $\mathrm{Ca}^{2+}$ signals are observed in mice, $\mathrm{Xe}$ nopus oocytes, and PC12 cells expressing presenilin mutations (Guo et al., 1996; Leissring et al., 1999; Stutzmann et al., 2004). In a compelling study, Tu et al. (2006) show that wild-type, but not mutant presenilins, form low-conductance divalent-cationpermeable ion channels in planar lipid bilayers. The authors suggest that expression of mutant presenilins leads to loss of the normal endoplasmic reticulum $\mathrm{Ca}^{2+}$ leak current and therefore cause an increased loading of the $\mathrm{Ca}^{2+}$ store, which would explain the exaggerated $\mathrm{Ins}_{3}$-mediated $\mathrm{Ca}^{2+}$ signals observed by previous studies with expression of presenilin mutations. Recently, it has also been observed that, in animal models of starved mice used to mimic the low glucose uptake/metabolism observed in the brains of individuals with $\mathrm{AD}$, reduced glucose uptake resulted in decreased protein O-GlcNAcylation (Liu et al., 2004). Therefore, another contributor to the enhancement of $\mathrm{InsP}_{3}$ evoked $\mathrm{Ca}^{2+}$ release observed in FAD can be explained with our finding that decreased $\mathrm{O}$-GlcNAcylation of the $\mathrm{InsP}_{3} \mathrm{R}-\mathrm{I}$ in- 
creases $\mathrm{Ca}^{2+}$ release. This new mechanism of regulation of the $\mathrm{Ins}_{3} \mathrm{R}-\mathrm{I}$ may also prove relevant for understanding the potential role of $\mathrm{Ca}^{2+}$ signaling disruptions in sporadic AD.

Under physiological conditions, the InsP $\mathrm{P}_{3} \mathrm{R}$-I channel couples activation of cell surface receptors to intracellular $\mathrm{Ca}^{2+}$ release. Regulation of the $\operatorname{Ins}_{3} \mathrm{R}$-I channel is thought to be a major component in the determination of the spatiotemporal characteristics of agonist-evoked $\mathrm{Ca}^{2+}$ signals (Berridge, 1993). Previous studies have shown that $O$-GlcNAcylation is a dynamic and inducible modification (for review, see Wells et al., 2001). We have shown that $O$-GlcNAcylation of the $\mathrm{InsP}_{3} \mathrm{R}-\mathrm{I}$ can be modulated both in vitro and in vivo. These modifications present a new mechanism of regulation of the $\mathrm{InsP}_{3} \mathrm{R}-\mathrm{I}$ channel, which may emerge as a major player in the control of fundamental cellular processes regulated by changes in the cytosolic $\mathrm{Ca}^{2+}$ concentration.

\section{References}

Akimoto Y, Kreppel LK, Hirano H, Hart GW (2000) Increased O-GlcNAc transferase in pancreas of rats with streptozotocin-induced diabetes. Diabetologia 43:1239-1247.

Berridge MJ (1993) Inositol trisphosphate and calcium signalling. Nature 361:315-325.

Bezprozvanny I (2005) The inositol 1,4,5trisphosphate receptors. Cell Calcium 38:261-272.

Bezprozvanny I, Watras J, Ehrlich BE (1991) Bell-shaped calcium-response curves of Ins $(1,4,5) \mathrm{P}_{3^{-}}$and calcium-gated channels from endoplasmic reticulum of cerebellum. Nature 351:751-754.

Choe CU, Ehrlich BE (2006) The inositol 1,4,5trisphosphate receptor (IP3R) and its regulators: sometimes good and sometimes bad teamwork. Sci STKE 2006:re15.

Clark RJ, McDonough PM, Swanson E, Trost SU, Suzuki M, Fukuda M, Dillmann WH (2003)

Diabetes and the accompanying hyperglycemia impairs cardiomyocyte calcium cycling through increased nuclear O-GlcNAcylation. J Biol Chem 278:44230-44237.

Comer FI, Vosseller K, Wells L, Accavitti MA, Hart GW (2001) Characterization of a mouse monoclonal antibody specific for $\mathrm{O}$-linked $N$-acetylglucosamine. Anal Biochem 293:169-177.

Ehrlich BE, Kaftan E, Bezprozvannaya S, Bezprozvanny I (1994) The pharmacology of intracellular $\mathrm{Ca}^{2+}$-release channels. TiPs 15:145-149.

Gao Y, Wells L, Comer FI, Parker GJ, Hart GW (2001) Dynamic $\mathrm{O}$-glycosylation of nuclear and cytosolic proteins: cloning and characterization of a neutral, cytosolic beta- $N$-acetylglucosaminidase from human brain. J Biol Chem 276:9838-9845.

Go LO, Moschella MC, Watras J, Handa KK, Fyfe BS, Marks AR (1995) Differential regulation of two types of intracellular calcium release channels during end-stage human heart failure. J Clin Invest 95:888-894.

Guo Q, Furukawa K, Sopher BL, Pham DG, Xie J, Robinson N, Martin GM, Mattson MP (1996) Alzheimer's PS-1 mutation perturbs calcium homeostasis and sensitizes PC12 cells to death induced by amyloid betapeptide. NeuroReport 8:379-383.

Hajnoczky G, Csordas G, Madesh M, Pacher P (2000) Control of apoptosis by IP(3) and ryanodine receptor driven calcium signals. Cell Calcium 28:349-363.

Haltiwanger RS, Blomberg MA, Hart GW (1992) Glycosylation of nuclear and cy-

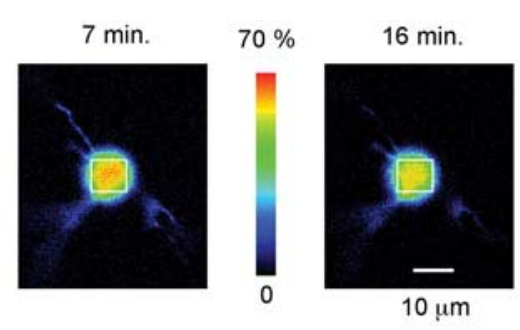$$
\mu \mathrm{m}
$$

UDP-GICNAC

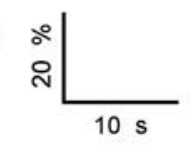

Control
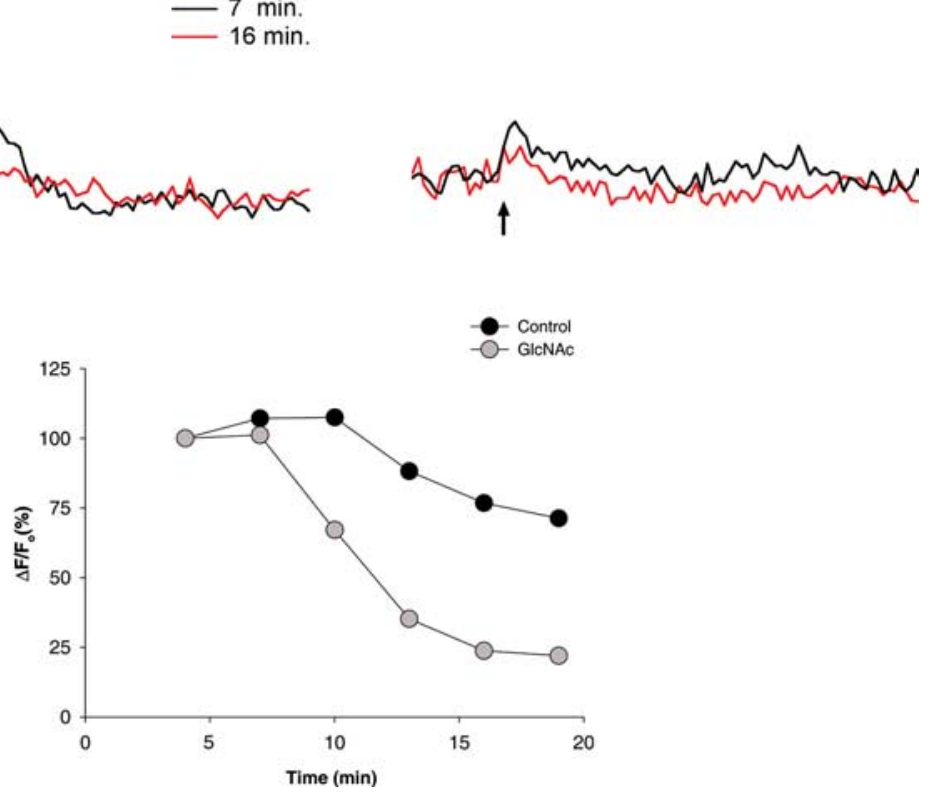

0

Figure 6. Uncaging of $\mathrm{Ins}_{3}$ elicits calcium release in cerebellar interneurons. $A$, Pseudocolor images of $0 \mathrm{G} 1 \mathrm{Ca}^{2+}$-dependent fluorescence from a postnatal day 12 interneuron at the peak of the response to photorelease of caged Ins $P_{3}$. The images on the left

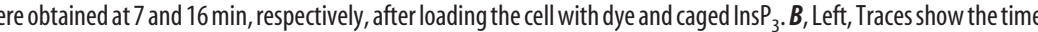

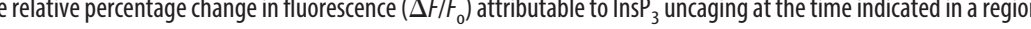
(identified by the white boxes in $\boldsymbol{A}$ ) of a cell preloaded with $0 \mathrm{G} 1$ and caged InsP. Right, Traces from an

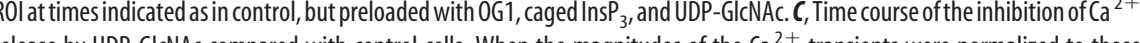
release by UDP-GICNAc compared with control cells. When the magnitudes of the $\mathrm{Ca}^{2+}$ transients were normalized to those obtained initially, responses decreased more rapidly from cells loaded with UDP-GICNAc than control cells.

toplasmic proteins. Purification and characterization of a uridine diphospho- $N$ acetylglucosamine:polypeptide beta- $N$-acetylglucosaminyltransferase. J Biol Chem 267:9005-9013.

Haltiwanger RS, Grove K, Philipsberg GA (1998) Modulation of O-linked $\mathrm{N}$-acetylglucosamine levels on nuclear and cytoplasmic proteins in vivo using the peptide $\mathrm{O}$-GlcNAc-beta- $\mathrm{N}$-acetylglucosaminidase inhibitor $\mathrm{O}$-(2-acetamido-2-deoxy-D-glucopyranosylidene)amino- $N$-phenylcarbamate. J Biol Chem 273:3611-3617.

Helenius A, Aebi M (2004) Roles of N-linked glycans in the endoplasmic reticulum. Annu Rev Biochem 73:1019-1049.

Hu Y, Belke D, Suarez J, Swanson E, Clark R, Hoshijima M, Dillmann WH (2005) Adenovirus-mediated overexpression of $O$-GlcNAcase improves contractile function in the diabetic heart. Circ Res 96:1006-1013.

Jayaraman T, Ondrias K, Ondriasova E, Marks AR (1996) Regulation of the inositol 1,4,5-trisphosphate receptor by tyrosine phosphorylation. Science 272:1492-1494.

Johenning FW, Zochowski M, Conway SJ, Holmes AB, Koulen P, Ehrlich BE (2002) Distinct intracellular calcium transients in neurites and somata integrate neuronal signals. J Neurosci 22:5344-5353.

Kreppel LK, Blomberg MA, Hart GW (1997) Dynamic glycosylation of nuclear and cytosolic proteins. Cloning and characterization of a unique $O-G l c N A c$ transferase with multiple tetratricopeptide repeats. J Biol Chem 272:9308-9315.

Kruglikov I, Gryshchenko O, Shutov L, Kostyuk E, Kostyuk P, Voitenko N 
(2004) Diabetes-induced abnormalities in ER calcium mobilization in primary and secondary nociceptive neurons. Pflügers Arch 448:395-401.

Launer LJ (2005) Diabetes and brain aging: epidemiologic evidence. Curr Diab Rep 5:59-63.

Lefebvre T, Ferreira S, Dupont-Wallois L, Bussiere T, Dupire MJ, Delacourte A, Michalski JC, Caillet-Boudin ML (2003) Evidence of a balance between phosphorylation and O-GlcNAc glycosylation of Tau proteins-a role in nuclear localization. Biochim Biophys Acta 1619:167-176.

Leissring MA, Paul BA, Parker I, Cotman CW, LaFerla FM (1999) Alzheimer's presenilin-1 mutation potentiates inositol 1,4,5-trisphosphatemediated calcium signaling in Xenopus oocytes. J Neurochem 72:1061-1068.

Liu F, Iqbal K, Grundke-Iqbal I, Hart GW, Gong CX (2004) $O-G l c N A c y l a t i o n$ regulates phosphorylation of tau: a mechanism involved in Alzheimer's disease. Proc Natl Acad Sci USA 101:10804-10809.

Liu J, Pang Y, Chang T, Bounelis P, Chatham JC, Marchase RB (2006) Increased hexosamine biosynthesis and protein $O$-GlcNAc levels associated with myocardial protection against calcium paradox and ischemia. J Mol Cell Cardiol 40:303-312.

Llano I, Gerschenfeld HM (1993) Inhibitory synaptic currents in stellate cells of rat cerebellar slices. J Physiol 468:177-200.

Llano I, Tan YP, Caputo C (1997) Spatial heterogeneity of intracellular $\mathrm{Ca} 2+$ signals in axons of basket cells from rat cerebellar slices. J Physiol 502:509-519.

Lubas WA, Hanover JA (2000) Functional expression of O-linked GlcNAc transferase. Domain structure and substrate specificity. J Biol Chem 275:10983-10988.

Marshall S, Duong T, Orbus RJ, Rumberger JM, Okuyama R (2003) Measurement of UDP- $N$-acetylglucosaminyl transferase (OGT) in brain cytosol and characterization of anti-OGT antibodies. Anal Biochem 314:169-179.

McNay EC, Williamson A, McCrimmon RJ, Sherwin RS (2006) Cognitive and neural hippocampal effects of long-term moderate recurrent hypoglycemia. Diabetes 55:1088-1095.

Michikawa T, Hamanaka H, Otsu H, Yamamoto A, Miyawaki A, Furuichi T, Tashiro Y, Mikoshiba K (1994) Transmembrane topology and sites of $N$-glycosylation of inositol 1,4,5-trisphosphate receptor. J Biol Chem 269:9184-9189.

Nagase T, Ito KI, Kato K, Kaneko K, Kohda K, Matsumoto M, Hoshino A, Inoue T, Fujii S, Kato H, Mikoshiba K (2003) Long-term potentiation and long-term depression in hippocampal CA1 neurons of mice lacking the IP(3) type 1 receptor. Neuroscience 117:821-830.

Nagy T, Champattanachai V, Marchase RB, Chatham JC (2006) Glucosamine inhibits angiotensin II-induced cytoplasmic $\mathrm{Ca}^{2+}$ elevation in neonatal cardiomyocytes via protein-associated O-linked $\mathrm{N}$-acetylglucosamine. Am J Physiol 290:C57-C65.

Parker GJ, Lund KC, Taylor RP, McClain DA (2003) Insulin resistance of glycogen synthase mediated by $\mathrm{O}$-linked $\mathrm{N}$-acetylglucosamine. J Biol Chem 278:10022-10027.

Robinson KA, Weinstein ML, Lindenmayer GE, Buse MG (1995) Effects of diabetes and hyperglycemia on the hexosamine synthesis pathway in rat muscle and liver. Diabetes 44:1438-1446.

Ryan CM (2006) Diabetes and brain damage: more (or less) than meets the eye? Diabetologia 49:2229-2233.

Snow CM, Senior A, Gerace L (1987) Monoclonal antibodies identify a group of nuclear pore complex glycoproteins. J Cell Biol 104:1143-1156.

Stutzmann GE, Caccamo A, LaFerla FM, Parker I (2004) Dysregulated IP3 signaling in cortical neurons of knock-in mice expressing an Alzheimer'slinked mutation in presenilin 1 results in exaggerated $\mathrm{Ca}^{2+}$ signals and altered membrane excitability. J Neurosci 24:508-513.

Tandon A, Fraser P (2002) The presenilins. Genome Biol 3:reviews3014.

Tang TS, Tu H, Wang Z, Bezprozvanny I (2003) Modulation of type 1 inositol $(1,4,5)$-trisphosphate receptor function by protein kinase $\mathrm{A}$ and protein phosphatase $1 \alpha$. J Neurosci 23:403-415.

Thinakaran G, Sisodia SS (2006) Presenilins and Alzheimer disease: the calcium conspiracy. Nat Neurosci 9:1354-1355.

Thrower EC, Choe CU, So SH, Jeon SH, Ehrlich BE, Yoo SH (2003) A functional interaction between chromogranin $\mathrm{B}$ and the inositol 1,4,5trisphosphate receptor/Ca ${ }^{2+}$ channel. J Biol Chem 278:49699-49706.

Tu H, Nelson O, Bezprozvanny A, Wang Z, Lee SF, Hao YH, Serneels L, De Strooper B, Yu G, Bezprozvanny I (2006) Presenilins form $\mathrm{ER} \mathrm{Ca}^{2+}$ leak channels, a function disrupted by familial Alzheimer's disease-linked mutations. Cell 126:981-993.

Wells L, Hart GW (2003) O-GlcNAc turns twenty: functional implications for post-translational modification of nuclear and cytosolic proteins with a sugar. FEBS Lett 546:154-158.

Wells L, Vosseller K, Hart GW (2001) Glycosylation of nucleocytoplasmic proteins: signal transduction and O-GlcNAc. Science 291:2376-2378.

Wessels AM, Simsek S, Remijnse PL, Veltman DJ, Biessels GJ, Barkhof F, Scheltens P, Snoek FJ, Heine RJ, Rombouts SA (2006) Voxel-based morphometry demonstrates reduced grey matter density on brain MRI in patients with diabetic retinopathy. Diabetologia 49:2474-2480.

Wojcikiewicz RJ, Luo SG (1998) Phosphorylation of inositol 1,4,5trisphosphate receptors by cAMP-dependent protein kinase. Type I, II, and III receptors are differentially susceptible to phosphorylation and are phosphorylated in intact cells. J Biol Chem 273:5670-5677.

Yang X, Su K, Roos MD, Chang Q, Paterson AJ, Kudlow JE (2001) $O$-Linkage of $N$-acetylglucosamine to Spl activation domain inhibits its transcriptional capability. Proc Natl Acad Sci USA 98:6611-6616.

Zachara NE, Hart GW (2006) Cell signaling, the essential role of O-GlcNAc! Biochim Biophys Acta 1761:599-617.

Zachara NE, O’Donnell N, Cheung WD, Mercer JJ, Marth JD, Hart GW (2004) Dynamic O-GlcNAc modification of nucleocytoplasmic proteins in response to stress. A survival response of mammalian cells. J Biol Chem 279:30133-30142. 